\title{
Determinants of Agricultural Protection: The Role of Democracy and Institutional Setting
}

\author{
Alessandro Olper
}

(Manuscript received March 2000; Revision received and accepted February 2001)

\begin{abstract}
7 his paper deals with the effects of democracy and institutional setting on agricultural protection in 35 developed and developing countries during 19821992. Regression analysis is conducted to test the effects of three alternative measures of democracy and two composite indices of the quality of institutions that protect and enforce property rights. After controlling for many other political and economic determinants of agricultural protection, the paper shows that democracy affects protection positively, but it is not the level of democracy per se that seems to matter. On the contrary there is strong evidence that the quality of institutions that protect and enforce property rights is a key determinant of agricultural protection. This empirical result is robust to changes in institutional proxy, country sample and statistical problems.
\end{abstract}

\section{Introduction}

In the last two decades there has been a notable body of literature dedicated to analysing the determinants of agricultural protection from a political economy perspective (see Swinnen and van der Zee, 1993, and de Gorter and Swinnen, 1994, for recent surveys). Much of the analysis is empirical, and uses data of agricultural protection to find the most relevant political and economic factors affecting agricultural policy. A major shortcoming is that much of this literature does not deal with the actual institutional setting in which policy formation takes place (Beghin and Fafchamps, 1995), disregarding the nature of political and economic institutions that are themselves important determinants of both redistributive and public good agricultural policies. Institutional factors constrain, both

Dipartimento di Economia e Politica Agraria, Agroalimentare e Ambientale, Università degli Studi di Milano. Via Celoria 2, 20133 Milano, Italy. E-mail: alessandro.olper@unimi.it for correspondence. The author thanks Francesco Lechi and Dario Casati for helpful comments on an earlier draft. Many thanks also to Philip E. Keefer (World Bank), for providing the BERI indicators. Lastly, the author wishes to thank the Editor and the Referees for their helpful suggestions. This research was carried out as part of the MURST (Ministero dell'Università e della Ricerca Scientifica) project: 'Conseguenze economiche e commerciali delle scelte di politica agricola comunitaria e internazionale'.

' See also the analysis of Bates (1983) on the food policy patterns in African countries. 
directly and indirectly, the decision-making process through their action on the level of competition in the political system and in conditioning the ability of groups to give weight to their interests (Olson, 1965; North, 1990).

Some recent analyses that attempt to cover this gap can be found in the studies of Beghin and Kherallah (1994) and Beghin et al. (1996). ${ }^{1}$ They have shown that institutions matter, and suggest that the interaction between political institutions and agricultural protection is non-linear and non monotonic. For example, effort towards democracy results in higher protection, then rent dissipation occurs with more competitive political markets (Beghin and Kherallah, 1994). Despite the interesting results of these studies, many aspects of the interaction between institution and agricultural protection remain unclear. For example, the sign of the relationship between democracy and protection is theoretically uncertain. Moreover, there is no direct addressing of important institutional dimensions highlighted in the theoretical literature, such as institutions that protect and enforce property rights (North, 1990; Rausser, 1992). Finally, due to the frequently subjective nature of many political institution proxies, it is important to test whether the empirical regularities are robust to changes in specifications, country sample and institutional proxies. Some of these issues will be addressed in the present work.

Following the work of Honma and Hayami (1986) and Beghin and Kherallah (1994) the present study takes an empirical approach based on quasi-reduced form estimation to analyse the cross-country time series consistency of the effects of democracy and institutional setting on agricultural protection. The period covered is from 1982 to 1992 and 35 countries - 13 OECD (counting the EU as one country), 18 developing and NIC and 4 CEEC - are considered. Similar data were used in a preliminary analysis on this topic in Olper (1999).

The empirical specification uses several alternative measures to capture the level of democratic pluralism, and different proxies of institution quality that protect and enforce property rights. The objective is to identify, and separate, the potential impact of these "different" institutional dimensions on agricultural policy. This can be important because, as stressed by de Gorter and Swinnen, recent literature linking political institution factors to macroeconomics government behaviour and economic growth suggests that focusing on political regimes (authoritarianism versus democracy) may be too simple to explain differences in performance and governance. A crucial issue is the credible commitment of government with respect to property rights and the enforcement of commercial rule (de Gorter and Swinnen, 1995: 281). Thus, it is not the level of democracy per se that matters, but other institutional dimensions, such as rules of law, bureaucratic quality and government credibility. The results reported in this paper strongly support this.

After controlling for many other political and economic determinants of agricultural protection, it can be seen that agricultural protection shows a positive, but weak, link with the level of democracy, and exhibits a strong inverse U-shaped pattern with the quality of institutions that protect and enforce property rights.

The paper is divided into four sections. Following the introduction, Section 2 gives some preliminary consideration to possible links between democracy and agricultural

\footnotetext{
'See also the analysis of Bates (1983) on the food policy patterns in African countries.
} 
protection, derives estimating equations, describes the data and reports empirical results. Section 3 reports and discusses the link between proxy of institution quality that protects and enforces property rights and agricultural protection. Finally, Section 4 discusses the implication of our findings and draws some conclusions.

\section{Democracy and agricultural protection}

\section{Theoretical and empirical considerations}

From a theoretical point of view the relationship between democracy and redistributive policies, such as agricultural protection, is an intriguing matter. All things being equal, why should the agricultural sector in a democratic regime be better than in an autocratic?

According to Przeworsky (1991) one of the main differences between democratic and authoritarian regimes lies in the level, in the political process, of free participation by independent organisations. Authoritarian regimes abhor independent organisations, and either incorporate them into centralised control or repress them by force. Starting from this there is the possibility of developing two contrasting viewpoints about whether agricultural protection is more, or less, likely to occur under democratic or authoritarian regimes.

One view is that the voices of farmers may be better heard in an electoral democracy (Lindert, 1991) where the interest groups are free to compete for political rents. This is because the high level of political rights permits farm groups to agitate for above-market rents. Instead authoritarian regimes, better able to discourage rent-seeking activities by interest groups, tax or do not support their agricultural sectors. These arguments suggest that in democracy, agricultural protection could be increasing.

Contrasting the above mentioned view is the probability of governments passing inefficient policy to benefit specific interest groups or "insiders", a probability that is actually higher under authoritarian regimes. Indeed, an important difference between democratic and authoritarian regimes is the degree of outsider influence. In a wellfunctioning democracy outsiders vote and impose some limits on what narrower interest groups can achieve, while in a less democratic environment the government needs to worry only about groups that have real power (Banerji and Ghanem, 1995). Thus it could be suggested that agricultural policy transfers could decrease in democracy, but the arguments are also consistent with a non-linear or non-monotonic relationship. Thus, from this brief discussion it emerges that, theoretically, the net effect of democracy on agricultural protection is of an uncertain sign; a result that, in general, agrees with the existing empirical evidence summarised below.

Support for a positive link between democracy and agricultural transfer is provided by many national examples and, interestingly, by empirical evidence inside and outside the agricultural economic literature. For example, literature that has analysed the relationship between democratic political regimes and government spending has shown that more pluralistic systems are normally associated with a greater budget deficit (see for example, Grilli et al., 1991). Thus, it can be inferred that part of this deficit is due to farm policy redistribution. Direct evidence can be found in Lindert (1991). In a cross-country analysis he found a positive relationship when democracy (captured by dummy variables) was associated with rapid agricultural decline. Moreover, in an analysis of agricultural protection in Belgium, Swinnen et al. (2000a) found that more political rights, such as the 
introduction of the Singular General Voting Scheme ("One Man, One Vote"), increased agricultural protection. At the same time, however, they found that other reforms that increase political rights have had no substantial effects on protection. The logical interpretation of this finding suggested by the authors is that only those political reforms which induce a significant shift in the political balance towards agricultural interest led to an increase in agricultural protection (p. 24).

This latest argument may explain the numerous examples in the empirical literature that support a decreasing or non-linear relationship between democracy and agricultural protection. Cases of non-democratic (or less democratic) countries that protect agricultural sectors can be found in Taiwan, Korea, Turkey, Chile, and Nigeria during the late 1970s and in 1980 (see Tyers and Anderson, 1992; USDA, 1994) and in almost all exCommunist countries (OECD, 1998). Moreover, democracies where agricultural sectors are discriminated against, or where there is no substantial protection, lend further credence to this view. Evidence can be found not only in less stable democracies like Argentina and Colombia, but also in long-stable democracies like India in the developing world and Australia and New Zealand in the developed one.

More general evidences of a decreasing or non-linear relationship can be found in cross-country analyses. Swinnen et al. $(2000 \mathrm{~b})$ found that moving from low to medium political rights reduces protection, but that a further increase in political rights has no substantial effects on agricultural protection. An opposite, but still non-linear behaviour, is shown in Beghin and Kherallah (1994) and Beghin et al. (1996). They found support for an inverse U-shaped pattern: dominant party systems are associated with more transfers than pluralist systems, which are in turn associated with more transfers than noparty systems.

Finally, as in the above discussion, empirical growth literature also emphasises ambiguity in the relationship between democracy and economic growth (see Przeworsky and Limongi, 1993, for a recent critical survey). Some studies have found positive effects of political rights on growth, but almost all fail to find a significant strong correlation. Barro (1997) suggests that this may be because the relation is non-linear: extensions of democracy appear to be beneficial only up to a threshold point. However, the same author concludes that democracy and political rights do not seem to be a critical factor in explaining economic performance.

\section{Model, data and measures}

The basic multivariate model to test the effects of democracy on agricultural protection is

$$
p_{i t}=\alpha+\beta x_{i t}+\gamma y_{i t}+u_{i t}
$$

where the subscripts refer to country $i$ and time $t ; p$ denotes the level of protection and support accorded by the government to agricultural sectors; $x$ is a political variable designed to capture the level of democracy; $y$ is a vector of control variables (taken from the literature) that measure economic and political conditions; $u$ is the error. The data set comprises 35 countries over the period from 1982 to 1992: in all there are 330 observations.

The dependent variable is the aggregated producer subsidy equivalent (PSE) as a percentage of gross farm income. Thus it measures the percentage of farm income that comes from all government programmes. The PSE includes border measures, output 
subsidies and direct payments as well as primary and intermediate input subsidies, structural policies and the effect of indirect macroeconomic policies such as the overvalued exchange rate (Webb et al., 19.90). The rationale for the choice of this variable is twofold: firstly, it is available for a quite large cross-section of countries due to the relative simplicity of its computation; secondly, measuring the level of total income transfer from consumer/taxpayer to the agricultural sector appears appropriate to test political economy hypotheses. ${ }^{2}$

Three alternative political variables are used to test the impact of democracy on agricultural protection. First, in line with the study of Beghin et al. (1996), we measure the degree of pluralism or the diversity of political parties using three dummy variables: multiparty democracy (SYS1), dominant party systems (SYS2) and authoritarian regimes (SYS3). Second, following Barro (1997), we use an indicator of political rights (PL) compiled by Gastil (1982-83). This is a subjective index that classifies countries into 7 categories, from the best (1) to the worst (7), on the basis of several dimensions such as the existence of free and fair elections, rights to participate in the political process, and so on. Finally, an index of democratisation (DEM) proposed by Vanhanen (1990) is used. This is based on proxies of competition and participation in the political system, compiled from electoral data. $D E M$ is not a dummy variable, it varies in continuum both across countries and over time, from 0 to 46.2 index points in our sample. Thus $D E M$ offers the possibility of detecting differences in the degree of pluralism of democratic countries. ${ }^{3}$

The other explanatory variables included to check for other political economy factors are: a factor endowment ratio to proxy for agricultural comparative advantage (FACTR); agricultural share in employment (EMPSHR) and in GDP (AGSHR) to account for differences in economic structure and industrialization; the per capita income (GDPC) to account for residual differences in development; the agricultural export value as a share of the value of total export (TAX1), and the share of income tax on total tax revenues (TAX2) to capture government tax collection constrains (Beghin and Kherallah, 1994). Such a choice of control variables is in accordance with the most recent empirical findings in this research area, taking into account data availability and is, in general, a less parsimonious choice than in previous studies (see, for example Honma and Hayami, 1986; Searker et al., 1993; Beghin et al., 1996)4. Appendix A reports summary statistics and the data source of the explanatory variables described above, Appendix B lists the country sample.

\section{Empirical results}

Table 1 shows the OLS regressions of four specifications: a basic specification that does not include the democracy variable; three different specifications that include the effects of the democracy variables described above. Let us briefly analyse the basic specification

\footnotetext{
2 For similar analyses that use different protection indices, also in comparison with the PSE measure, see Beghin and Kherallah (1994) and Olper (1998).

${ }^{3}$ Note that both theoretical and empirical evidence suggest differences in the public finance outcome between democracies with a different degree of pluralism, such as presidential vs. parliamentary systems (see Tabellini, 2000; Grilli et al., 1991).

${ }^{4}$ Other determinants suggested by the literature, such as the agricultural term of trade, were tried but without significant results. Regression was also run including as proxy of comparative advantage the ratio of agricultural labour productivity over manufacturing labour productivity, instead of FACTR (see Hanma and Hayami, 1986). The resulting coefficient was negative and statistically significant as in previous analyses. In the final regressions we prefer the specification with FACTR due to the potential endogenity issue of the productivity ratio and collinearity problems with $T A X I$. However, the results are both qualitatively and quantitatively the same. For a more extensive description and justification of the explanatory variables described above, see Olper (1999).
} 
(regression (i)). Overall the empirical results are very close to the previous studies. All the "traditional" political and economic determinants of the protection levels enter in the equation with their expected sign and are, for the most part, statistically significant at 1 or 5 per cent levels. Protection increases in countries with a comparative disadvantage in agriculture (Honma and Hayami, 1986). Protection is negatively related to the relative dimensions of the agricultural sector as measured by farm number (EMPSHR), in line with the collective action hypothesis (Olson, 1965). However, the relation is positive and significant when the economic role of agriculture is measured as the share of GDP ( $A G S H R$ ), a result that is frequently found in the most recent empirical analyses that use specifications very close to this study (see Beghin and Kherallah, 1994; Swinnen, et al., $2000 \mathrm{~b}$ ). Moreover, protection is positively associated with economic development (GDPPR), in line with the so-called development paradox. Finally, export revenue tax diversification (TAX1) and tax instrument diversification (TAX2), are respectively negatively and positively related to agricultural protection; nevertheless the coefficient of tax instrument diversification is insignificant. Thus there is little support for the hypothesis, suggested by Beghin et al. (1996), that when income taxation becomes more prevalent taxation on agricultural exports decreases.

Table 1: Effects of Democracy on Agricultural Protection

\begin{tabular}{lcccc}
\hline Independent variables & (i) & (ii) & (iii) & (iv) \\
\hline Intercept & 20.85 & 10.07 & 33.56 & 19.33 \\
& $(1.89)$ & $(0.88)$ & $(2.27)$ & $(1.75)$ \\
Comparative advantage (FACTR) & -86.78 & -82.76 & -85.65 & -86.06 \\
& $(5.76)$ & $(5.34)$ & $(5.86)$ & $(5.73)$ \\
Employment share (EMPSHR) & -1.053 & -1.074 & -1.044 & -1.047 \\
& $(3.56)$ & $(4.04)$ & $(3.59)$ & $(3.53)$ \\
Agricultural GDP share (AGSHR) & 1.371 & 1.674 & 1.489 & 1.401 \\
& $(2.42)$ & $(3.31)$ & $(2.64)$ & $(2.47)$ \\
Agricultural Export Share (TAXI) & -0.372 & -0.450 & -0.411 & -0.386 \\
& $(2.72)$ & $(3.11)$ & $(3.03)$ & $(2.81)$ \\
Share of income tax (TAX2) & 0.143 & 0.129 & 0.123 & 0.151 \\
& $(1.41)$ & $(1.28)$ & $(1.24)$ & $(1.48)$ \\
Real per-capita GDP (GDPC) & 0.003 & 0.002 & 0.003 & 0.003 \\
& $(5.01)$ & $(3.73)$ & $(3.35)$ & $(3.95)$ \\
Pluralist party system (SYS1) & & 21.07 & & \\
& & $(3.71)$ & & \\
Dominant party system (SYS2) & & 13.24 & & \\
Political rights (PL) & & $(0.88)$ & & \\
Index of democratization (DEM) & & & -3.019 & $(1.86)$ \\
\hline Adj. R & & & & \\
No. obs. & 0.45 & 0.46 & 0.45 & 0.459 \\
\hline
\end{tabular}

Notes: Dependent variable PSE. Parentheses () give the absolute heteroskedasticity-consistent t-staristics of White (1980). 
The estimated effects of the three democracy variables on the full sample of 35 countries are reported at the bottom of Table 1, regressions from (ii) to (iv). If the political dummy variable is used as an indicator of democracy (Column (ii)), only the coefficient of SYS1 is positive and significant at the l per cent level, suggesting that protection is higher in most pluralist systems. If PL (Column (iii)) or DEM (Column (iv)) is used as the democracy variable the regression coefficient is respectively negative and positive, in line with the above result, but of less statistical significance ( 10 per cent level). There is no evidence of a non-linear relationship: e.g. the coefficient of SYS2 is not statistically different from zero. Similar results are obtained if $D E M$ or $P L$ enter in the equation in a quadratic form. In these cases the t-values of both the linear and square coefficients are insignificant.

Note also that using $D E M$ as the democracy variable does not improve the performance of the regression. Thus, there is no evidence that in democratic countries the differences in the degree of pluralism affect the level of agricultural protection. Finally, comparing basic regression (i) with regressions from (ii) to (iv) reveals that the inclusion of the democracy variables, despite their coefficients being statistically significant, does not add significant information to the model.5

This preliminary examination of the link between democracy and agricultural protection suggests that protection increases in democracy and with political rights; however we cannot conclude from this evidence that political rights play a critical role in agricultural support, a result that is not new in the literature (see Swinnen et al., 2000b). Thus, on returning to the discussion of the previous section it can be seen that these results provide only weak support for the hypothesis that high levels of political rights give farm groups a more sensitive political environment for their rent-seeking activities. However the finding does not mean that authoritarian regimes are immune to rent-seeking behaviour, but, more simply, that the groups who have real power in these countries are outside the rural sectors. ${ }^{5}$ A possible explanation of the weak effect of democracy on agricultural protection can be found in the Swinnen et al. (2000a) hypothesis, which stresses that only those political reforms that determine a significant shift in the political balance towards agricultural interests give an increase in agricultural protection. However, the data do not support the non-linear relationship between democracy and protection often found in this literature (see below). ${ }^{7}$

A major shortcoming of this conclusion could be due to other omitted factors correlated to democracy levels, that could bias estimated coefficients. The following section also looks into this point.

\section{Quality of institution and agricultural protection}

\section{Hypothesis, data and measures}

From the perspective of political economy, few would dispute that the security of

\footnotetext{
5 The $F$-statistics for basic regression (i) versus regressions that include democracy variables is always lower than the critical $F$-value at both the 5 and 10 per cent levels.

${ }^{6}$ For example, Banerji and Ghanem find strong empirical support for the hypothesis that in an authoritarian setting, urban labour and owners of capital tend to have greater relative power, since the majority of rural and informal workers are not allowed to vote and cannot organise urban unrest and demonstrations to bring down the government (1995: 24).

7 Nevertheless, the non-linear evidences found in the previous cross-country studies did not go in the same direction. In particular, Beghin and Kherallah (1994) and Beghin et al. (1996) find an inverted U-shaped relation between democracy and agricultrual protection, and Swinnen et al. (2000) find a U-shaped relation.
} 
property and contractual rights, and the efficiency with which governments manage the provision of public goods, are key determinants of agricultural taxation/subsidisation patterns and, more in general, of agricultural and economic growth (Binswanger and Deininger, 1997; Kriack and Keefer, 1995). The institutional setting - determined by the legal, bureaucratic and regulatory system - directly and indirectly constrains the decision making process through its action on the competitive level in the political system, and in conditioning the ability of groups to represent their interests. This is because institutions define the structure of participant incentive and opportunity, conditioning both economic and political exchange (de Gorter and Swinnen, 1995; Rausser, 1992; North, 1990).

Nevertheless, due in particular to limitations in data, the empirical examination of the link between institutions and agricultural protection has been largely restricted to qualitative country studies (e.g. Bates, 1989), reducing the possibility of a robust and more general test of the hypothesis. The notable exception to the above is in the work of Beghin and Kherallah (1994) and Beghin et al. (1996); they capture the role of institutional dimensions other than political regimes by the indicators of civil liberties compiled by Gastil. However, the limitation of these indices as a proxy of the security of property and contractual rights and government credibility is well known in the most recent empirical growth literature (see Knack and Keefer, 1995; Barro, 1997). In fact, the Gastil civil liberties index is an aggregate measure, compiled without the explicit aim of measuring the security of property and contractual rights; moreover, it is highly correlated with the democracy variables used in the previous section. ${ }^{8}$ Thus, the use of this index hinders any possibility of capturing any effects other than differences in the degree of democracy. Moreover, it is important to note that for 12 of the 13 OECD countries covered in this study, the Gastil index of civil liberties is equal to one (as for SYS1 and $P L$ ), precluding any possibility of capturing differences in the security of property rights and government credibility of around $1 / 3$ of the sample. 9

To overcome these limitations, and to analyse in greater depth the empirical relationships between institutions and agricultural policy, use was made of indicators compiled by two private international investment risk services: International Country Risk Guide (ICRG) and Business Environmental Risk Intelligence (BERI). These two sources provide detailed ratings for large samples on desegregated dimensions of property rights closely related to those institutions emphasised by theoretical work (Knack and Keefer, 1995). From ICRG use was made of five different institutional measures. Three - Expropriation Risk, Rule of Low and Government Repudiation - can be interpreted as direct proxies for the security of property and contract rights and government credibility. In countries that score low on these dimensions, the private actors cannot count on government and legal systems to respect contracts and property rights. Thus investment in economic and rent-seeking activities will be low because of a limited expected return and high transaction costs. For example, in agriculture, land

\footnotetext{
8 The correlation coefficents between the Gastil civil liberty index and the democratic variables are -0.76 with $S Y S I, 0.93$ with $P L$, and -0.85 with $D E M$.

${ }^{9}$ For this reason it is not surprising that in the regressions presented in section 3.2 , the inclusion of the Gastil index of civil liberties is never significant neither in the linear nor the quadratic form, or when included as categorical dummies as in Beghin and Kherallah (1994). For a critical discussion on the limit of the Gastil indices as proxy of the security property and contracted rights, also in comparison with the proxies used in this work, see Knack and Keefer (1995).
} 
tenure policies can be critical because the lack of clear land rights and institutions that make property rights effective can induce low levels of lobbying for farm policies (Beghin and Fafchamps, 1995). The other two institutional dimensions - Quality of Bureaucracy and Corruption in Government - are proxy for the general efficiency found in government services and their immunity from rent-seeking behaviour. Countries scoring low in these dimensions have a bureaucracy that lacks procedural clarity and technical competence, and it is likely that criteria other than efficiency will be introduced into the determination of government policies and in the allocation of public goods (Knack and Keefer, 1995).

The BERI measures used in this analysis are Contract Enforceability, Nationalization Potential and Bureaucratic Delays which are similar to the ICRG variables described above, and Infrastructure Quality that does not have analogues in the ICRG data set. This last variable may be interpreted as a proxy of the efficiency with which government allocates public goods. Moreover, because this variable assesses the quality of communication and transportation infrastructure, it is a direct proxy of the transaction costs inherent in farm group activities (Olson, 1985).

Following earlier works that use these measures (see, for example, Knack and Keefer, 1995; Svensson, 1998) the five ICRG variables and the four BERI variables were aggregated through simple addition to form two composite indices of the quality of institutions that protect and enforce contractual and property rights. 10 This arrangement is necessary to overcome correlation problems among separate indicators, with the consequent risk of multicollinearity, and in order to avoid omitting any of these institutional dimensions from the equation. It is important to note that there is no significant change in the results reported below when individual components of these indices are used.

\section{Empirical results}

The empirical results of the effect of institution quality on agricultural protection are reported in Table 2. If the ICRG indicator is entered linearly into the regressions of Table 1 , then the resulting coefficient is positive and statistically significant. However, the results shown in Table 2 (Columns from (i) to (iii)) allow for a quadratic relationship. Indeed, if the ICRG is entered in a quadratic form the linear coefficients, and its square, are both statistically significant at the 1 per cent level, and the explanatory power of the models is higher. Thus, to economise on space, we have reported only the last results.

Very similar results are found if the BERI index, not ICRG, is used as the indicator of institution quality (see Columns from (iv) to (vi)). In this case the sample drops from 35 to 29 countries due to the lack of $B E R I$ data. The main difference in this case is that if the $B E R I$ indicator is entered linearly into the regressions, the resulting coefficient is negative but statistically insignificant. However, both coefficients are significant at the 1 per cent level in the quadratic version reported in Table 2.

The institution quality variables are not only highly statistically significant, but also have strong explanatory power. Using the beta coefficient to determine which variable

\footnotetext{
${ }^{10}$ In general, the correlation between investor service proxies and the democracy variables is relatively low (or not so high), indicating that these institutional variables contain different and additional information. The coefficients are: $0.54,-0.63$ and 0.74 for $I C R G$, and $0.46,-0.59$ and 0.62 for $B E R I$, with respect to SYSI, PL and $D E M$ respectively.
} 
contributes the most to the regression, we find that both ICRG and BERI have the highest explanatory power."1 The beta coefficients for ICRG in the regressions of Table 2 have, on average, a value of 2.90 for the linear term and -2.81 for the quadratic term. The importance of this effect can be seen by comparing these values with the beta coefficient of the agricultural GDP share ( $A G S H R$ ) or the level of development (GDPC), that have the greatest explanatory power after ICRG. The beta coefficient for these variables has an absolute value never higher then 0.40 , showing that $I C R G$ is the most important variable in explaining protection. There is a similar story with regard to the $B E R I$ indicator. Its beta coefficient is on average 0.73 for the linear term and -0.80 for the quadratic. Thus, $B E R I$ performs less well than ICRG, but still exhibits a beta coefficient higher than the other control variables.

Table 2: Effects of Quality of Institutions on Agricultural Protection

\begin{tabular}{|c|c|c|c|c|c|c|}
\hline \multirow[b]{2}{*}{ Independent variables } & \multicolumn{3}{|c|}{ ICRG } & \multicolumn{3}{|c|}{ BERI } \\
\hline & (i) & (ii) & (iii) & (iv) & (v) & (vi) \\
\hline FACTR & $\begin{array}{c}-66.51 \\
(5.43)\end{array}$ & $\begin{array}{r}-69.77 \\
(6.35)\end{array}$ & $\begin{array}{c}-70.21 \\
(4.21)\end{array}$ & $\begin{array}{r}-60.43 \\
(8.73)\end{array}$ & $\begin{array}{c}-62.08 \\
(8.62)\end{array}$ & $\begin{array}{r}-61.43 \\
(8.56)\end{array}$ \\
\hline EMPSHR & $\begin{array}{l}-0.866 \\
(3.72)\end{array}$ & $\begin{array}{l}-0.730 \\
(2.95)\end{array}$ & $\begin{array}{l}-0.717 \\
(2.83)\end{array}$ & $\begin{array}{l}-0.591 \\
(2.51)\end{array}$ & $\begin{array}{l}-0.568 \\
(2.48)\end{array}$ & $\begin{array}{l}-0.569 \\
(2.47)\end{array}$ \\
\hline$A G S H R$ & $\begin{array}{r}2.293 \\
(4.14)\end{array}$ & $\begin{array}{c}2.006 \\
(3.30)\end{array}$ & $\begin{array}{c}1.952 \\
(3.21)\end{array}$ & $\begin{array}{c}0.848 \\
(2.01)\end{array}$ & $\begin{array}{c}0.722 \\
(1.78)\end{array}$ & $\begin{array}{r}0.679 \\
(1.70)\end{array}$ \\
\hline TAX1 & $\begin{array}{l}-0.603 \\
(4.73)\end{array}$ & $\begin{array}{l}-0.600 \\
(4.93)\end{array}$ & $\begin{array}{l}-0.585 \\
(4.94)\end{array}$ & $\begin{array}{l}-0.656 \\
(7.57)\end{array}$ & $\begin{array}{l}-0.615 \\
(7.01)\end{array}$ & $\begin{array}{l}-0.596 \\
(6.84)\end{array}$ \\
\hline TAX2 & $\begin{array}{c}0.162 \\
(1.64)\end{array}$ & $\begin{array}{r}0.159 \\
(1.65)\end{array}$ & $\begin{array}{r}0.229 \\
(2.30)\end{array}$ & $\begin{array}{r}0.206 \\
(2.43)\end{array}$ & $\begin{array}{r}0.205 \\
(2.32)\end{array}$ & $\begin{array}{r}0.220 \\
(2.46)\end{array}$ \\
\hline$G D P C$ & $\begin{array}{c}0.003 \\
(3.47)\end{array}$ & $\begin{array}{c}0.003 \\
(3.62)\end{array}$ & $\begin{array}{c}0.004 \\
(4.69)\end{array}$ & $\begin{array}{c}0.002 \\
(3.87)\end{array}$ & $\begin{array}{c}0.003 \\
(3.99)\end{array}$ & $\begin{array}{r}0.003 \\
(3.82)\end{array}$ \\
\hline SYSI & $\begin{array}{l}18.78 \\
(3.58)\end{array}$ & & & $\begin{array}{l}16.72 \\
(3.52)\end{array}$ & & \\
\hline SYS2 & $\begin{array}{l}26.35 \\
(1.98)\end{array}$ & & & $\begin{array}{l}-1.105 \\
(0.16)\end{array}$ & & \\
\hline$P L$ & & $\begin{array}{l}-4.888 \\
(2.75)\end{array}$ & & & $\begin{array}{l}-1.437 \\
(1.36)\end{array}$ & \\
\hline$D E M$ & & & $\begin{array}{r}0.687 \\
(3.86)\end{array}$ & & & $\begin{array}{r}0.211 \\
(1.50)\end{array}$ \\
\hline Quality of institutions & $\begin{array}{l}13.97 \\
(5.14)\end{array}$ & $\begin{array}{l}14.56 \\
(4.85)\end{array}$ & $\begin{array}{l}15.28 \\
(5.11)\end{array}$ & $\begin{array}{l}16.87 \\
(3.35)\end{array}$ & $\begin{array}{l}17.79 \\
(3.73)\end{array}$ & $\begin{array}{l}14.98 \\
(2.73)\end{array}$ \\
\hline Quality of institutions ${ }^{2}$ & $\begin{array}{c}-0.819 \\
(4.83)\end{array}$ & $\begin{array}{c}-0.202 \\
(4.65)\end{array}$ & $\begin{array}{l}-0.219 \\
(5.01)\end{array}$ & $\begin{array}{l}-0.921 \\
(3.79)\end{array}$ & $\begin{array}{l}-0.99 \\
(4.30)\end{array}$ & $\begin{array}{l}-0.842 \\
(3.15)\end{array}$ \\
\hline Adj. $R^{2}$ & 0.55 & 0.54 & 0.54 & 0.57 & 0.55 & 0.55 \\
\hline No. obs. & 330 & 330 & 330 & 277 & 277 & 277 \\
\hline
\end{tabular}

Notes: Dependent variable PSE. Parentheses ( ) give the absolute heteroskedasticity-consistent $t$ - statistics of White (1980). Constants not reported.

II The beta coefficients were calculated by dividing the standardized estimated coefficients by the standard deviation of the dependent variables, so as to 'purge' the estimated coefficients of their dependence on measurement units. 
Now let us turn to the interpretation of this empirical evidence. A positive coefficient in the linear term and a negative coefficient in the square suggests that protection increases with institution quality at low levels of this dimension, but the relation turns negative once a moderate amount of institution quality has been achieved. One way to interpret this empirical evidence is that in countries where the institution is poor in protecting and enforcing property rights, any improvement in these dimensions will allow an increase in farm political pressure due to the reduction of lobbying costs and the increase in expected return from rent-seeking activities. However, when a country has already achieved a moderate level of institution efficiency, any further increase in the quality of institution reduces protection (and distortion), probably because the dominant effect in this new setting comes from an increase in the competition between lobbies and in the ability of government to select more efficient policies. Thus, there is evidence that credible institutions that protect rules and property rights, reducing uncertainty, have an effect in minimizing deadweight losses and rent-seeking opportunities (Beghin and Fafchamps, 1995).

The inclusion of institution quality variables also affects the performance of the democracy indicators discussed in Section 2. However, the results are mixed in this regard. The magnitude of the effects of the democracy indices increases in the specifications with $I C R G$ and its square. For example, in these specifications $D E M$ and $P L$ are statistically significant at the 1 per cent level, and their coefficients increase in magnitude. Thus, there is some evidence that the coefficients of the democracy indicators reported in Table 1 are biased. However, in the specifications with BERI we find an opposite effect. In fact, the coefficients of the democracy indices are now smaller and $P L$ and $D E M$ are insignificant at the conventional statistical level. ${ }^{12}$ Finally, it is important to note that the three democracy measures have an absolute beta coefficient never higher then 0.17 , reinforcing the conclusion of the previous section on the weak effects of democracy on agricultural protection.

In summary, even though there are some mixed effects, probably due to some multicolinearity problems, the conclusions of the interplay between democracy and agricultural protection suggest that democracy affects protection positively, but it is not the level of democracy per se that seems to matter. On the contrary there is strong evidence that the quality of institutions conditioning the economic and political incentives of the actors, is a key determinant of agricultural protection.

\section{Sensitivity analysis}

In this subsection we briefly discuss three possible problems with the regressions discussed above. A first problem can be derived by reverse causation leading to simultaneity bias, as suggested by Beghin and Kherallah (1994). The three right-hand side variables, $A G S H R, T A X 1$ and $T A X 2$, are the best candidates for potential endogenity problems. Columns (i) and (ii) of Table 3 show results from two-stage least-square (2SLS) regressions for two representative specifications that include $P L$ as the democratic indicator. ${ }^{13}$ The instruments include $A G S H R, T A X 1$ and TAX2 all lagged two years, and

\footnotetext{
12 Note that these results are not due to the change in the country sample. Indeed, if we use $I C R G$ and its square instead of $B E R I$ in the sample of 29 countries used for $B E R I$ regressions, the coefficients of $D E M$ and $P L$ increase, but only the former is statistically significant.

${ }^{13}$ The specification with DEM or political system dummy SYSI and SYS2 give similar results, thus to save space, we have not reported these regressions.
} 
the other right-hand side variables of the specification (ii) and (iii) of Table 2. As can be seen, 'the parameter estimates suggest that our results and conclusions are not substantially affected by endogenity problems.

The two other possible econometric problems derive from the cross-sectional time-series nature of our data. Indeed, OLS estimation of Tables 1 and 2 assume that the error terms, $\mathrm{u}_{\mathrm{it}}$, are independent and identically distributed. However, this assumption is open to question for pooled data, which may exhibit correlation of the error term over time for a given country, as well as cross-section effects at a given point in time.

To check if serial correlation affects our results, we re-run regressions using the NeweyWest correction, that gives consistent estimates of the covariance matrix in the presence of both heteroskedasticity and autocorrelation (Newey and West, 1987). The results of this correction are reported in columns (iii) and (iv) of Table 3. In general, the results for specification with ICRG and its square are essentially unchanged and all the estimated

Table 3: Regression of the Sensitivity Analysis

\begin{tabular}{|c|c|c|c|c|c|c|}
\hline \multirow[b]{2}{*}{ Independent variables } & \multicolumn{2}{|c|}{ 2SLS } & \multicolumn{2}{|c|}{ N-W correction } & \multicolumn{2}{|c|}{ Fixed-effects } \\
\hline & (i) & (ii) & (iii) & (iv) & (v) & (vi) \\
\hline FACTR & $\begin{array}{l}-77.2 \\
(6.43)\end{array}$ & $\begin{array}{c}-60.37 \\
(6.82)\end{array}$ & $\begin{array}{c}-69.77 \\
(4.26)\end{array}$ & $\begin{array}{c}-62.08 \\
(4.81)\end{array}$ & $\begin{array}{c}-62.41 \\
(5.22)\end{array}$ & $\begin{array}{c}-44.32 \\
(7.43)\end{array}$ \\
\hline EMPSHR & $\begin{array}{l}-0.623 \\
(2.26)\end{array}$ & $\begin{array}{c}-0.306 \\
(1.50)\end{array}$ & $\begin{array}{c}-0.730 \\
(1.72)\end{array}$ & $\begin{array}{c}-0.568 \\
(1.56)\end{array}$ & $\begin{array}{l}-0.446 \\
(1.39)\end{array}$ & $\begin{array}{c}-0.046 \\
(0.18)\end{array}$ \\
\hline$A G S H R$ & $\begin{array}{r}2.023 \\
(3.30)\end{array}$ & $\begin{array}{c}0.453 \\
(1.24)\end{array}$ & $\begin{array}{r}2.006 \\
(2.35)\end{array}$ & $\begin{array}{c}0.722 \\
(1.25)\end{array}$ & $\begin{array}{c}2.556 \\
(3.71)\end{array}$ & $\begin{array}{c}1.989 \\
(3.98)\end{array}$ \\
\hline$T A X 1$ & $\begin{array}{l}-0.417 \\
(3.21)\end{array}$ & $\begin{array}{l}-0.668 \\
(6.50)\end{array}$ & $\begin{array}{l}-0.600 \\
(3.41)\end{array}$ & $\begin{array}{l}-0.615 \\
(3.82)\end{array}$ & $\begin{array}{l}-0.781 \\
(6.17)\end{array}$ & $\begin{array}{l}-0.758 \\
(9.25)\end{array}$ \\
\hline$T A X 2$ & $\begin{array}{c}0.103 \\
(0.95)\end{array}$ & $\begin{array}{r}0.177 \\
(1.91)\end{array}$ & $\begin{array}{r}0.159 \\
(0.97)\end{array}$ & $\begin{array}{c}0.205 \\
(1.34)\end{array}$ & $\begin{array}{r}0.113 \\
(1.20)\end{array}$ & $\begin{array}{c}0.234 \\
(2.55)\end{array}$ \\
\hline$G D P C$ & $\begin{array}{c}0.004 \\
(3.90)\end{array}$ & $\begin{array}{c}0.003 \\
(3.62)\end{array}$ & $\begin{array}{c}0.003 \\
(2.16)\end{array}$ & $\begin{array}{c}0.003 \\
(2.34)\end{array}$ & $\begin{array}{r}0.003 \\
(2.71)\end{array}$ & $\begin{array}{c}0.002 \\
(2.56)\end{array}$ \\
\hline$P L$ & $\begin{array}{l}-4.908 \\
(2.47\end{array}$ & $\begin{array}{l}-2.130 \\
(1.48)\end{array}$ & $\begin{array}{l}-4.888 \\
(1.79)\end{array}$ & $\begin{array}{l}-1.437 \\
(0.83)\end{array}$ & $\begin{array}{c}-5.576 \\
(2.94)\end{array}$ & $\begin{array}{l}-1.301 \\
(1.30)\end{array}$ \\
\hline$I C R G$ & $\begin{array}{l}12.39 \\
(3.35)\end{array}$ & & $\begin{array}{l}14.56 \\
(3.35)\end{array}$ & & $\begin{array}{l}16.22 \\
(4.58)\end{array}$ & \\
\hline ICRGSQ & $\begin{array}{l}-0.169 \\
(3.21)\end{array}$ & & $\begin{array}{l}-0.202 \\
(3.18)\end{array}$ & & $\begin{array}{l}-0.220 \\
(4.08)\end{array}$ & \\
\hline$B E R I$ & & $\begin{array}{l}18.39 \\
(3.49)\end{array}$ & & $\begin{array}{l}17.80 \\
(2.04)\end{array}$ & & $\begin{array}{l}22.49 \\
(4.71)\end{array}$ \\
\hline BERISQ & & $\begin{array}{l}-0.987 \\
(3.74)\end{array}$ & & $\begin{array}{l}-0.99 \\
(2.30)\end{array}$ & & $\begin{array}{l}-0.892 \\
(3.83)\end{array}$ \\
\hline Regional dummies & NO & NO & NO & NO & YES & YES \\
\hline Adj. $\mathrm{R}^{2}$ & (a) & (a) & 0.54 & 0.55 & 0.57 & 0.67 \\
\hline No. obs. & 260 & 219 & 330 & 277 & 330 & 277 \\
\hline
\end{tabular}

Notes: Dependent variable PSE. Parentheses ( ) give the absolute heteroskedasticity-consistent $t$ statistics of White (1980) in regressions (i), (ii), (v) and (vi), and the heteroskedasticity-serial-correlation-consistent $t$-statistic of Newey and West (1987) in regressions (iii) and (iv). Regional fixed-effects and constants not reported. 
coefficients remain statistically significant at the 5 and 10 per cent levels. In the specification with $B E R I$ and its square, the coefficients of EMPSHR and $A G S H R$ have their expected signs but the t-values are behind the conventional statistical level. Nevertheless, both the BERI coefficient and its square remain significant at the 5 per cent level, so our conclusions regarding the significant non-linearity effect of $B E R I$ are still valid.

What is more difficult is to test whether our results are affected by individual effects due to the cross-sectional nature of the data. The quasi time invariant of the institutional proxies complicates the empirical examination as it is not possible to adopt a fixed-effect framework using country-specific dummies. A rough test to check whether individual effects affect the results to any degree is to use regional dummies. We estimated the previous specifications using regional dummies related to: Latin America, Africa, Asia (India and China), Korea, ex-Communist and the OECD countries. The results of these specifications are reported in Table 3, columns (v) and (vi). When regional dummies (base "region" = OECD) are included, the results are similar to the regressions in Table 2 (columns (ii) and (v)), in the sense that almost all the estimated coefficients remain statistically significant with their expected sign. Thus, country individual effects appear to have little effect on our results, ceteris paribus. The only notable exception to this conclusion is the coefficient of EMPSHR, that is now negative but statistically insignificant. Thus we have only partial empirical support for the so-called "paradox of number" suggested by Olson (1985).

In the specification with ICRG and its square, the dummies for Asia and the African countries show a significantly negative effect whereas for Korea it is positive. On the other hand, in the specification with $B E R I$ and its square, all the regional dummies are found to be significant, with a positive coefficient for the ex-Communist countries, Korea and Latin America, and a negative one for Asia and the African countries. Finally, note also that in the BERI regression, if regional dummies are added, the increase in the explanatory power of the model is greater (compare column (vi), Table 3, with column (v), Table 2). Thus, in line with the evidence of the previous section, these results reinforce the conclusion that ICRG is a better indicator to capture the institutional dimension that affects agricultural policy.

\section{Conclusion}

The aims of this paper were to analyse the link between agricultural protection and political institutions, with the objective of clarifying and separating the role played by democracy and the quality of institutions that protect and enforce property and contractual rights. The empirical finding offers support for two main conclusions. First, after controlling for agricultural comparative advantage, economic structure and development, and tax collection constraints, it can be seen that the level of protection is higher in more pluralistic and democratic countries. However, democracy does not seem a crucial factor in explaining protection because its explanatory power is low and the statistical significance is not so robust to changes in specification. While this result is rather different with respect to some previous empirical studies, it is important to note that we find a positive relationship between political rights and protection using three different democracy indicators. Moreover, the fact that using a continuum indicator of democracy, 
such as $D E M$, does not change the relationship, suggests that "further" democratisation or differences in the degree of pluralism do not affect the level of agricultural protection. Indirectly, this result gives some credence to the Swinnen et. al. (2000a) view, which conditions the effect of an increase in political rights on agricultural protection, to the shift in the political balance towards farmers induced by political reforms.

Second, and this is most interesting, the quality of the institutions that protect and enforce property rights is an important determinant of agricultural taxation/subsidisation patterns, showing a strong non-linearity effect: at low levels of these dimensions an increase in institution quality enhances protection (or reduces taxation) but the relation turns negative once a moderate amount of institution quality has been attained. Furthermore, the sensitivity analysis shows that this empirical result is robust to changes in institutional proxy, country sample and statistical problems.

This empirical finding supports the idea that it is the nature of public institutions, through their action on the incentive structure and in conditioning the level of transaction costs, that is a critical element in the "performance" of the policy-making process. In other words, good rules of the game and government credibility minimising rent-seeking opportunities allow a more efficient policy outcome (Beghin and Fafchamps, 1995).

A direct implication of these findings is that creating and reforming political institutions that protects and enforces property rights in developing countries should be an important priority in the agenda for policy reform. However, this policy recommendation could be useless when we recognise that it is the same forces that shape public policy that, in the long-run, also affect institutions (Swinnen and de Gorter, 1995). We are a still long way from understanding the complex interaction between institution, policy outcome and performance.

However, if the property rights structure is a key determinant of farm policy distortion, one way to further investigate this line of research is to look at the factors affecting the persistence of inefficient institutions, and to connect them through simple analytical models to policy outcomes. An example in this direction can be found in the literature that has incorporated stylised notions of property rights and rent-seeking into formal models (see, for example Svensson, 1998). The Svensson model shows the relationship between socio-political instability and government incentive to fully protect property rights through legal reform, and the effect of the said property rights on investment and growth. Empirical tests strongly support the casual link of the models. Thus, an extension of the analysis of the interplay between institution and agricultural policy in the above mentioned directions could offer an interesting insight into this research field.

\section{References}

Banerji, A. and Ghanem, H. (1995). Political Regimes, Trade and Labour Policies in Developing Countries, World Bank, Working Paper Series, May 1995.

Barro, Robert J. (1997). Determinants of Economic Growth: A Cross-country Empirical Study. MIT Press, Cambridge. Bates, R. H. (1983). Patterns of Market Intervention in Agrarian Africa, Food Policy, November, 297-304.

Bates, R. H. (1989), Beyond the Miracle of the Market. The Political Economy of Agrarian Development in Kenya, Cambridge University Press, Cambridge.

Beghin, J.C. and Fafchamps, M. (1995). Constitution, Institutions and the Political Economy of Farm Policies: 
What Empirical Content? in Peters, G.H. and Hedley, Douglas D. (eds.), Agricullural Competitiveness: Market Forces and Policy Choire, Aldershot, Dartmouth, 287-295.

Beghin, J.C., Foster, W.E, and Kherallah, M. (1996). Institutions and Market Distortions: International Evidence for Tobacco, Journal of Agriculiural Economics, 47 (3), 355-365.

Beghin, J.C. and Kherallah, M. (1994). Political Institutions and International Patterns of Agricultural Protection, Review of Economics and Statistics, LXXVI, 482-489.

Binswanger, H. P. and Deininger, K. (1997). Explaining Agricultural and Agrarian Policies in Developing Countries, Joumal of Economic Literature, XXXV(4), 1958-2005.

De Gorter, H. and Swinnen, J. (1994). The Economic Polity of Farm Policy, Journal of Agricultural Economics, 45, 312-326.

De Gorter, H. and Swinnen, J. (1995). The Political Economy and Institutional Determinants of Public Policy in Agriculture, in Peters, G.H. and Hedley, Douglas D. (eds.), Agnicultural Competitiveness: Market Forces and Policy Choice, Aldershot, Dartmouth, 274-286.

Gastil, R.D. (1982-83 and other years). Freedom in the World, Greenwood Press, Westport CT.

Grilli, V., Masciandaro, D. and Tabellini, G. (1991). Political and Monetary Institutions and Public Finance Policies in the Industrial Countries, Economic Policy, 13 (October), 341-392.

Honma, M. and Hayami, Y. (1986). Structure of Agricultural Protection in Industrial Countries, Journal of International Economics, 20, 115-129.

Knack, S. and Keefer, P. (1995). Institutions and Economic Performance: Cross-country Tests Using Alternative Institutional Measures, Economics and Politics, 7, 207-227.

Lindert, H.L. (1991). Historical Patterns of Agricultural Policy, in Timmer C.P. (editor), Agriculture and the State. Grotuth, Employment, and Poverty in Developing Countries, Cornell University Press, Ithaca, 29-83.

Newey, W. K. and West, K. D. (1987). A Simple Positive Semi-Definite, Heteroskedasticity and Auto-correlation Consistent Estimates of Co-variance Matrix, National Bureau of Economic Research, Technical Working Paper No. 55, Cambridge, MA, April.

North, D. (1990). Institutions, Institutional Change and Econonic Performance, Cambridge University Press, Cambridge.

OECD (1998). Agricullural Policies in Emerging and Transition Economies: Monitoring and Eualuation, Paris.

Olper, A. (1998). Political Economy Determinants of Agricultural Protection Levels in EU Member States: An Empirical Investigation, European Review of Agricultural Economics, 25(4), 461-485.

Olper, A. (1999). Istituzioni Politiche, Diritti di Proprietà e Sostegno del Settore Agricolo, Rivista di Economia Agraria, n. 4.

Olson, M. (1965). The Logic of Collective Action. Public Goods and the Theory of Groups, Harvard University Press, Cambridge.

Olson, M. (1985). Space, Agriculture, and Organization, American Journal of Agricultural Economics, 67, 928-973 Przeworsky, A. (1991). Democracy and the Market. Cambridge University Press, Cambridge.

Przeworsky, A. and Limongi, F. (1993). Political Regimes and Economic Growth, Journal of Economic Perspectives, 7 (Summer), 51-69.

Rausser, G.C. (1992), Predatory Versus Productive Government: The Case of U.S. Agricultural Policies, Journal of Economic Perspective, 6(3), 133-157.

Sarker, R., Meilke, K. and Hoy, M. (1993). The Political Economy of Systematic Government Intervention in Agriculture, Canadian Journal of Agricultural Economics, 41 (3), 289-309.

Svensson, J. (1998). Investment, Property Rights and Political Instability: Theory and Evidence, European Economic Revien, 42, 1317-1341.

Swinnen, J., Banerjee, A. N. and de Gorter, H. (2000a). Economic Development, Institutional Change, and the Political Economy of Agricultural Protection: an Econometric Study of Belgium since 19th Century, Working Paper no. 8, Policy Research Group, Department of Agricultural Economics, Katholieke Universiteit Leuven, Belgium.

Swinnen, J., de Gorter, H., Rausser, G.C. and Banerjee, A. N. (2000b). The Political Economy of Public Research Investment and Commody Policy in Agriculture: An Empirical Study, Agricullural Economics, 22, 111-122.

Swinnen, J. and van der Zee, F. A. (1993). The Political Economy of Agricultural Policies: A Survey, European Review of Agricullural Economics, 20, 261-290.

Tabellini, G. (2000). Constitutional Determinants of Government Spending, IGIER and Department of 
Economics, Boccony University, February 2000.

Tyers, R. and Anderson, K. (1992). Disarray in World Food Markets. Cambridge University Press, Cambridge.

USDA/ERS (1994). Producer and Consumer Subsidy Equivalent, http://usda.mannlib.cornell.edu/datasets/international.

Vanhanen, T. (1990): The Process of Democratisation: A Comparalive Study of 147 Stales, 1980-1988, New York, Crane Russak.

Webb, A., Lopez, M. and Penn, R. (1990). Estimates of Producer and Consumer Subsidy Equivalents: Government Intervention in Agriculture, 1982-87, USDA, ERS, Statistical Bulletin No. 803, Washington, DC.

White, H. (1980). A Heteroskedasticity-Consistent Covariance Matrix and a Direct Test for Heteroskedasticity, Econometrica, 48, 817-838.

Appendix A. Variable Definition, Data Source and Summary Statistics

\begin{tabular}{|c|c|c|c|}
\hline Variable & Definition and source & Mean & Std. Dev. \\
\hline$P S E:$ & Producer subsidy equivalent. Source: USDA and OECD. & 17.62 & 55.76 \\
\hline FACTR: & $\begin{array}{l}\text { Ratio of agricultural land per farm worker to real GDP per } \\
\text { capita. Source: FAO and World Bank. }\end{array}$ & 0.14 & 0.19 \\
\hline EMPSHR : & $\begin{array}{l}\text { Ratio of total active people in agriculture to total labour force in } \\
\text { the economy. Source: FAO. }\end{array}$ & 28.04 & 25.75 \\
\hline AGSHR : & $\begin{array}{l}\text { Ratio of agricultural value added to total GDP. Source: World } \\
\text { Bank. }\end{array}$ & 11.58 & 11.10 \\
\hline TAX1: & $\begin{array}{l}\text { Ratio of total agricultural export to total merchandise export. } \\
\text { Source: USDA. }\end{array}$ & 20.00 & 22.59 \\
\hline TAX2: & $\begin{array}{l}\text { Taxes on income and corporate profit as a share of total tax } \\
\text { revenue. Source: World Bank. }\end{array}$ & 31.28 & 16.36 \\
\hline$G D P C:$ & $\begin{array}{l}\text { Real per capita GDP in international dollars. Source: World } \\
\text { Bank. }\end{array}$ & $7,995.00$ & $5,916.00$ \\
\hline SYS1: & $\begin{array}{l}\text { Dummy variable taking the value } 1 \text { for multiparty system and } \\
\text { O otherwise. from Beghin and Kherallah (1994). }\end{array}$ & 0.65 & 0.48 \\
\hline SYS2: & $\begin{array}{l}\text { Dummy variable taking the value } 1 \text { for dominant party aystem } \\
\text { and } 0 \text { otherwise, from Beghin and Kherallah (1994). }\end{array}$ & 0.09 & 0.29 \\
\hline SYS3: & $\begin{array}{l}\text { Dummy variable taking the value } 1 \text { for one party and no-party } \\
\text { system and } 0 \text { otherwise, from Beghin and Kherallah (1994). }\end{array}$ & 0.26 & 0.44 \\
\hline$P L:$ & $\begin{array}{l}\text { Gastil index of Political Rights. Source: Freedom House: } \\
\text { http://www.freedomhouse.org/. }\end{array}$ & 2.78 & 1.98 \\
\hline$D E M:$ & Index of democratisation, from Vanhanen (1990). & 17.31 & 14.26 \\
\hline$I C R G$ : & $\begin{array}{l}\text { Index of institutional quality, aum of: rule of low, corruption } \\
\text { in government, quality of bureacracy, expropriation of private } \\
\text { investment, repudiation of contracts. Source: ICRG. New } \\
\text { York, see Knack and Keefer (1995) for a detailed definition. }\end{array}$ & 35.26 & 11.13 \\
\hline BERI: & $\begin{array}{l}\text { Index of institutional quality, sum of: bureaucratic delays, } \\
\text { nationalisation potential, contract enforceability. } \\
\text { infrastructure quality. Source: the data were provided by } \\
\text { Stephen Knack, see Knack and Keefer (1995) for a detailed } \\
\text { definition. }\end{array}$ & 9.68 & 2.46 \\
\hline
\end{tabular}


Appendix B. Country Sample and Time Period Covered

\begin{tabular}{|c|c|c|c|c|c|}
\hline 1 & Argentina & $' 82.92$ & 19 & Korea & '82.91 \\
\hline 2 & Australia & '82.92 & 20 & Mexico & '82.92 \\
\hline 3 & Austria & $' 82-92$ & 21 & New Zeland & '82-92 \\
\hline 4 & Brazil & '82-87 & 22 & Nigeria & '82-89 \\
\hline 5 & Canada & '82.92 & 23 & Norway & '82-92 \\
\hline 6 & Chile & 187.92 & 24 & Poland & '83-92 \\
\hline 7 & China & '84-92 & 25 & Senegal $^{(\mathrm{a})}$ & '82-89 \\
\hline 8 & Colombia & '82-92 & 26 & Slovakia & '86-92 \\
\hline 9 & Czech Republic & ' $86-92$ & 27 & South Africa & '82-89 \\
\hline 10 & Egypt & '82.92 & 28 & Sweden & '82.91 \\
\hline 11 & European Union & '82.92 & 29 & Switzerland & '82-92 \\
\hline 12 & Finland & '82-92 & 30 & Tanzania ${ }^{(a)}$ & '82-89 \\
\hline 13 & Hungary & '86-92 & 31 & Turkey & $82-92$ \\
\hline 14 & Iceland $^{(a)}$ & '82.92 & 32 & USA & '82-92 \\
\hline 15 & India & '82.90 & 33 & Venezuela & '82.87 \\
\hline 16 & Jamaica $^{(a)}$ & '82.89 & 34 & Zambia ${ }^{(\bullet)}$ & '82-91 \\
\hline 17 & Japan & '82.92 & 35 & Zimbabwe $^{(a)}$ & '82-89 \\
\hline 18 & Kenya & ' 82.89 & & & \\
\hline
\end{tabular}

(a) Countries not included in BERI sample. 